\title{
The Effectiveness of the Implementation of Character Education (An Evaluation Research in State Kindergarden, South Jakarta)
}

\author{
Silvie Mil \\ Muhammadiyah University of Prof. Dr. Hamka, Jakarta, Indonesia \\ Corresponding e-mail: silviesahara@gmail.com
}

\begin{abstract}
This study aimed to evaluate the effectiveness of the implementation of character education in state kindergarden, South Jakarta. This study uses a model developed by the CIPP Stufflebeam to evaluate the component context, input, process and product. Data collected through observation, interviews, document studies and questionnaires. Data were analysed, interpreted descriptively and then comparing the results with the success criteria specified. Findings reported in the context of components State Kindergarden is in conformity with the criteria of success. There is a document that shows the formal foundation and the work program of character education. The curriculum and the work program has been meeting people's expectations of the value a character who wants to be inculcated in children. On the input component of all learners have been grouped according to age standards but uneven distribution of students, especially for preschool, school capacity is also not optimal. Most teachers are highly qualified and have the necessary skills. Based curriculum development has been based on character education, which is based Permendiknas No. 58 of 2009 on Standards ECD evaluation results on infrastructure is in conformity with the criteria of success. The involvement of parents and school committees are very high in supporting the implementation of character education. Lesson plans already use the approach of pouring daily activity program character but is still made after the learning process is completed. In the process components, the ability of teachers and the involvement of students in the learning process is already well but still need better time management. In the process of assessment, there are no descriptive account format on the outcome of character education of children. This is not in accordance with defined criteria. In the product components are already there are changes in children's behavior towards the better but on daily and weekly reports learners are not descriptive explanation that does not meet the criteria for success.
\end{abstract}

Keywords: character education, CIPP model, evaluation program

\section{INTRODUCTION}

Character education is a process of cultivation of character values to learners, which includes awareness, understanding, awareness and commitment (Mulyasa, 2012: 69; Elkind \& Sweet, 2013) which involves cognitive, social, emotional and physical (Lickona, 1992: 51) that foster a sense of desire to do good (desiring the good) and became a behavior / action do well (Megawangi, 2007: 8283 ). Morison believes that early childhood is the age of the establishment, which children need to be taught about positive behavior and responsible for their own behavior (Morrison, 2012: 334). Moral behavior is received by a person for a long and slow process, but the moral foundations can already receive from infancy through moral codes that will guide the behavior and character of the child (Hurlock, 1980: 91). By providing character education at an early age through habituation, expected that children will have a good intelligence and personality, which will support their future Kindergarten as early childhood education institutions have an important role in character education of children. In this institution, there is a responsibility to help children control their own behavior, responsible, self-confidence, independence, and tolerance. Character education is done through habituation and exemplary educators in schools. Habituation and exemplary not only in one unit of teaching alone but in units of teaching holistically (the whole school reform), both teaching 
and learning activities in the classroom, daily activities in school culture (school culture), everyday life in the home and in the community (Budimansyah 2012: 20-21) All of these things should ideally be carried out in a holistic and integrated.

The phenomenon that is happening now is schools prefer academic education rather than of character education. Achievement is measured by the child's intellectual level and ranking. Education is considered less successful in delivering the generation of people into individuals with dignity. Many have successfully completed a variety of subjects with the right questions but does not have good mental personality, strong and independent. It becomes its own concerns for many people.

The root cause of this aberrant behavior in early childhood (Morrison, 2012: 334) early childhood education rated yet to implement character education in a comprehensive and thorough. Education in schools are sometimes not aware, that attitude to the child, sometimes even going to drop, for example, by hitting, put pressure on the child, which ultimately makes a child to be negative, low selfesteem, timid and did not dare to take risks, who eventually these characters will be taken until the adult child. When mature, the characters sort of thing would be a barrier to achieving and realizing the wishes of children.

Not so the case TK Negeri Latihan II, which is located on Jl. Halimun No. 2, South Jakarta. By observation, kindergarten located in densely populated areas, children demonstrate good behavior attitude. Children dispose of waste in place and maintain the cleanliness of the school even though their schools are enclosed gardens and houses empty. Children cared for games that use well and put them neatly in place. This is consistent with the indicators implementation in early childhood character that is the character of the discipline. Kids were able to order greeting and kissing the hand of all the teachers after the lesson ends. This raises the interest to learn more about how schools make their students as an orderly, polite and good character.

There are various opinions regarding the definition of the evaluation. Tyler stated that evaluation is the process of systematic assessments to identify standard criteria to the extent to which educational goals can be achieved where the results are used for decision-making (Tayipnapis, 2008: 3; Scriven in Davidson, 2005: 1; Stufflebeam and Shinkfiled, 2007: 16; Wirawan 2007: 7). From these opinions, can be concluded that the evaluation of a study conducted systematically, in which there are processes describe, collect, analyze and present information for decision-making.

The evaluation was conducted to assess the extent to which the effectiveness of the implementation of character education in kindergarten State Exercise II South Jakarta. In this study, evaluation model used is CIPP (Context, Input, Process, and Product) developed by Stufflebeam and Shinkfiled. Evaluation context (context) includes policy analysis and elaboration of programs headmasters on the implementation of character education programs and community needs related to the character to be formed. Evaluation inputs (input) to identify the characteristics of the child, teacher qualifications, character education curriculum, facilities and learning resources character education, finance management and lesson planning character education. Evaluation process (process) refers to the process of learning and assessment on character education. Evaluation of the product (product) assessing the goals and results of changes in children's behavior and the achievement of results reporting documentation.

\section{METHODS}

This study used a qualitative and naturalistic approach. Data collecting through participant observation; parents, teachers and principal interview, document studies; and parents, teachers and principal questionnaires. This study also use CIPP model from Stufflebeam as a model design. 


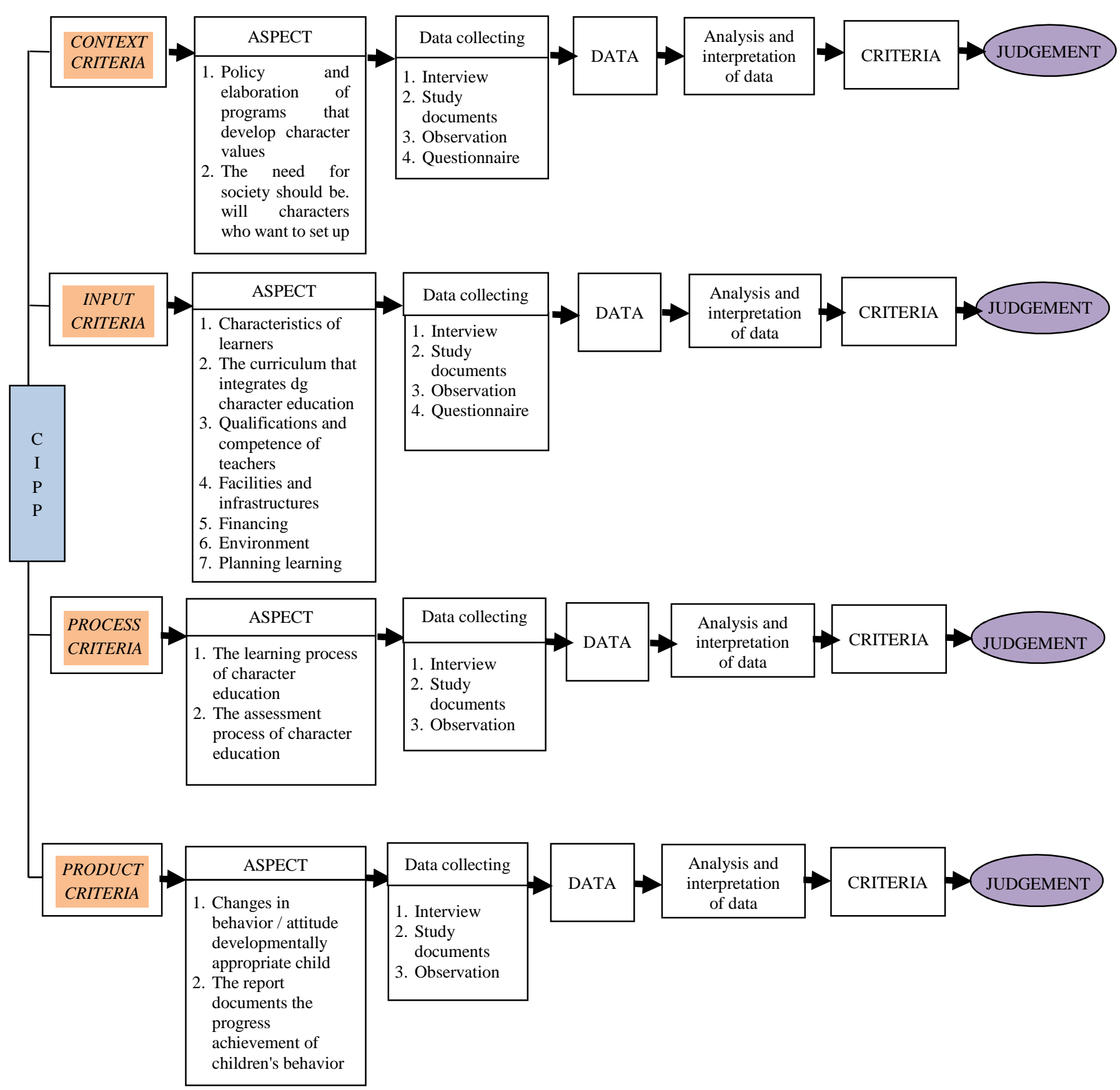

Figure 1. Design of Evaluation Study of Efectiveness of Character Education in State Kindergarden, South Jakarta

The research instrument is the researcher himself assisted with the interview guidelines, a checklist of documents, observation sheets, and questionnaires that have been validated both cons tract and the content by 5 experts and expert evaluation of early childhood program

\section{RESULT}

State Kindergarden in South Jakarta was established by the Department of Education and Culture of the Republic of Indonesia in 1975 on the grounds as a place of observation, research and field practice for students of the Jakarta State University Department of Psychology. Overall character education is 
already well integrated into the curriculum of State Kindergarden in South Jakarta. This is reflected in the vision and mission of the school to realize early childhood personality and noble, confident and independent. The programs there has also been developing a character, such as by behavioral development program, development potential, the development of character education syllabus approach and make the character values as indicators in the implementation of the Plan Daily Activities.

To support the implementation of character education, the principal also has set an agenda of activities in a year.

There are no selection tests in the acceptance of new learners, assessment is only beginning to see the initial capabilities possessed prospective students and possible candidates with special needs.

Grouping study groups are in accordance with the standards established by the Ministerial Regulation No. 58 Year 2009 on Standards ECD. State Kindergarden has four study groups consisting of one group Preschool ages 2-4 years, the Group A study group aged 4-5 years and two group B age group of 5-6 years.

Most of the teachers in kindergarten country is a graduate degree early childhood, the other is a nonearly childhood education graduates and high school graduates. Comparison between the number of teachers and enrollment for preschool is 1: 5, Group A 1: 10 and group B 1: 14-15 children.

Based on the evaluation, facilities and infrastructure in schools is sufficient to implement the learning process of character education. Most of the parents stated condition of the building, means the game is in the school yard, a good swing, slides, climbing arena, media, educational games the tools in good condition and well maintained and can be used for learning activities.

Allocation of funds for education in kindergarten country comes from two sources, namely from the National Education Department of DKI Jakarta Province and dues learners with the largest amount of funds derived from the contributions of learners. Allocation of funds coming from the government allocated for the shopping needs of office materials such as papers, pencils etc., a common printed material, cost of photocopy and used for meetings. Allocations are almost the same also applied to the funding that comes from the contributions of learners.

The results of the survey and observation found support from parents has been good. The support in the form of: 1) the high level of attendance to a meeting of parents in the socialization program / agenda of school activities; 2) the provision of facilities and infrastructure necessary for the child's character education as buying costume contest dances, etc. 3) Carry out the conditioning that has been modeled by teachers and schools to do well for the home, such as with custom greetings, kiss the hands of parents, washing hands before eating and another habituation. Other community support in the form of sponsorship funding companies that are in the school to fund and support the final parting of State Kindergarden of South Jakarta.

Learning plan itself was well planned, where the curriculum, academic calendar, the Annual Programmed, Semester Program, Weeks/Daily Activity Programs are planned on an ongoing basis and interrelated. Character values has become an indicator of success in learning is implemented daily.

In the process of learning, teachers have applied learning method in accordance with the principles of development and abilities of young children.

Integrating values in character education is included in Daily Activity Programs and became one of the indicators of achievement of children. The motivation of teachers in teaching is also high. Teachers are responsible for shaping the character of children in accordance with the values of character education. Approach to the child done personally so that children's understanding of the values of character that's better. Teachers always give an example imitation of habits, attitudes, behavior and speech that the implementation of the code that is more easily understood by learners. Character education assessment process carried out by several methods such as direct observation, question, and answer, anecdotal records, performance and compliment them on their child's success.

The results of this character education are the behavioural change among students so that a child is noble, independent, responsible by virtue of devotion to God Almighty. Besides the potentials that exist in children can be tapped and developed well during the learning takes place. These behavioural changes are already being felt directly by teachers and parents. Results are also reported the development of character education in the form of ratings daily, weekly and semi-annually.

\section{DISCUSSION}

In the context of the components of success criteria have been met and in terms of the formal foundation, and policy and program of work related to the school principal character education. There 
are only a few things to be improved in the low interest of teachers to read and understand the laws / regulations that underlie the policies and program of work Principal. Because by understanding the normative foundation will make the implementation of a program that teachers teaching more meaningful.

The needs of people who put character education have been accommodated by the school. Seen from the translation of the vision and mission of the school to form a child morality and develop the full potential of early childhood with by devotion to God Almighty. Vision mission these but then realized in the form of the agenda and the annual work program.

In the input and process components are interwoven between the two. In the aspect of learners, of total capacity amounting to \pm 90 school children in the school year 2013/2014, there were only 82 students are registered and accepted as new learners that were spread on each of the study groups have not been evenly distributed. Most of the group B is only a small fraction Group A and Group Play. This is because the number of applicants aged 5-6 years more than other age groups.

Almost all teachers have been trained but the quantity of training character education is still lacking, the need for periodic character education training, measurable, effective and fittion the ability and creativity of teachers in the teaching of character education can be optimized. There has been no initial of teachers volunteered to participate in training / seminar for the development of abilities and skills of teachers. The motivation of teachers in providing excellent teaching character education with persistent effort of teachers in instilling the values of the characters to the learners and extraordinary patience in educating children.

The materials related to character education has been comprehensively integrated into the curriculum, as well as very developmentally appropriate early childhood. The values of the characters into grains indicator of success in the learning process of children that the Plan Daily Activities (RKH) in the form of the value of discipline, honesty, responsibility, religious and love of the homeland. Allocation of time in character education be implemented along the learning activities. Media / learning resources are already integrated with other thematic learning. Both in quality and quantity of all sources and media that could be used for the implementation of character education. There is no separation between the educational facilities of character with other educational facilities because it is integrated with each other.

Financing character education itself is still in the post routine financing paid by the school. There are no special expense items for the implementation of character education. For character education training costs are still the cost allocation of Jakarta Education Agency. For RKH some teachers still put them after learning activities carried out not before learning activities. Based on the interview and this is because of time management problems.

In the process the components are still there is interference in the implementation of learning activities in the form of time management arrangements that are less good. Race preparation training schedule often uses study time effectively and make the concentration of other learners who are not participants in the race to be disturbed. Class condition with connecting doors between classes B1 and B2 are open to making learners from each class to visit each classroom next to him and disrupt the classroom teaching and learning the process. There are also one or two children who have special characters that need the extra handling, where sometimes if the child is having a bad mood, often interfere with other learners and disrupt the learning process.

In terms of the assessment process, there are still shortcomings in terms of the achievement description of the child's behavior in the form of a narrative on daily assessment format and the format of the weekly ratings. The report also less individualistic, so less observed per child development. In product and process components interconnected where daily and weekly reports only a symbol of a star without any narration. In addition to weekly assessment report, the results of educational attainment characters are not visible because the results of its own assessment incorporated in the development of moral values and social-emotional.

\section{CONCLUSIONS}

Based on the results of research and discussion, can be summed up as follows:

Evaluation context (context). a) The existence of a formal foundation of the policy implementation of character education in the form of Law Number 20 Year 2003 on National Education System, Government Regulation No. 19 Year 2005 on National Education Standards and Technical 
Guidelines for the Implementation of Education Kindergarten. Vision and mission of the school are appropriate that shape a child morality. Already, there are policies and programs of character education that are their self-development programs and development programs in the kindergarten behavior of state kindergarden. b) The need for community, curriculum, and school programs already accommodate the desire of people to shape the character.

On the evaluation of the input (input). a) Learners. There is no selection tests Admission only in the form of observation / assessment beginning. Learners have been grouped according to the age group where pre-school aged 2-4 years (group 1), Class A the age of 4-5 years (group 1) and class B aged 5-6 years (group 2). Total revenue FY $2013 / 2014$ was 82 children of the total capacity of \pm 90 school children. It does not fit the criteria for the distribution of students is uneven and needs additional promotional efforts so that the number of classrooms for more optimal Study Groups and the maximum capacity of the school to be fulfilled. b) Most teachers already meet the academic qualification and never follow training on character education, character education but need training that are scheduled and ongoing. c) The curriculum is in accordance with the criteria of success where kindergarten curriculum of State Kindergarden has developed behavior and potential as one of the work programs of the Principal. Time allocation character education took place during the learning process and resource/learning media integrated with other learning. d) The availability of facilities and infrastructure that support the implementation of character education integrated with other learning. The school has a media and learning resources that support character education. e) Funding for character education still fused to the financing of operational activities of everyday life, yet there is a special expense item to it that needs to be budgeted for expenditure for the implementation of character education, both for the purchase of media/learning resources, training for teachers and others. Required the allocation of funds and expenditure on the implementation of character education because it is a work program that involves a lot of things. f) Environment. Parental involvement in children's education is very high support in addition to the school committee also actively communicate and participate in children's activities such as competitions and other activities. g) There is a learning tool like the semester program, syllabus, Weeks/Daily Activity Program that develop character education. Syllabus, daily Activity Program has taken into account the development of the characters and already using the indicator value in Daily Activity Programs such character of patriotism, responsibility, honesty, and discipline. But need good time management in terms of casting the syllabus in the form Daily Activity Programs because in practice there are still teachers who make Daily Activity Programs after the learning is completed but it is also necessary supervision of the Principal to ensure that daily Activity Program has been made in accordance with the procedure.

For the evaluation process (process): a) The process of learning. Learning material character education tailored to the theme, teachers master the teaching materials and approaches / methods vary according to the needs of learners and the learning objectives, media/learning resources character education tailored to the theme but still constrained by lack of good time management, disruption of children who lack discipline in the classroom and a classroom setting. Need good time management arrangements, extra handling in particular children and closing the connecting door so that participants can be orderly in their respective classes. b) Assessment Process. Teachers conduct assessment throughout the learning process by using a variety of valuation techniques. Still, there is a mismatch in the format of the daily and weekly ratings are symbolic and not individually, only reports per semester which describe the development of character education of children individually and narrative. Expected future daily and weekly reports can be prepared in a narrative that achievement and developmental changes in children's behavior can be better monitored.

In the evaluation of the product (Product) which is the result of learning. In interviews with the parents / guardians of student there is a change of behavior on the learner. Only the report for daily and weekly reports only symbolic with no more meaning in narrative form. Only child per semester progress report that narrate the achievement of individual children's behavior so we recommend that schools should improve existing assessment format in order to be able to describe the development of character education at each learner are descriptive and individualistic. 


\section{REFERENCES}

Budimansyah, Dasim. (2012). Perancangan Pembelajaran Berbasis Karakter. Bandung: Widya Aksara Press, 20-21.

Elkind, David H dan Fred Sweet, How to Do Character. Retrieved March 28, 2016, from http://www.goodcharacter.com/Article_4.html

Hurlock, Elizabeth B. (2003). Developmental Psycology (A Life Span Approach). Boston: McGraw-Hill Inc, 91.

Lickona, Thomas. (1992). Educating For Character: How Our Schools Can Teach Respect and Responsibility. New York: Bantam Books, 51.

Megawangi, Ratna. (2007). Semua Berakar Pada Karakter :Isu-Isu Permasalahan Bangsa. Jakarta: Lembaga Penerbit FEUI, 82-83.

Morrison, George S. (2012). Dasar-Dasar Pendidikan Anak Usia Dini. Jakarta: Indeks, 334.

Mulyasa, E. (2012). Manajemen PAUD. Bandung: Remaja Rosdakarya, 69.

Stufflebeam, Daniel L., Anthony J Shinkfield. (2007). Evaluation, Theory, Models \& Applications. San Fransisco: John Wiley \& Sons Inc, 16.

Tayibnapis, Farida. (2008). Evaluasi Program dan Instrumen Evaluasi Untuk Program Pendidikan dan Penelitian. Jakarta: Rineka Cipta, 3.

Wirawan. (2007). Evaluasi: Teori, Model, Standar, Aplikasi dan Profesi. Jakarta: Rajawali Pers, 7. 